\title{
Modal Sosial Sebagai Strategi Pemulihan Pasca Gempa di Desa Gondang Kecamatan Gangga Kabupaten Lombok Utara
}

\author{
Wen Farizi Zullam ${ }^{1}$, Syarifuddin, Maya Atri Komalasari \\ Universitas Mataram
}

\begin{abstract}
The study was entitled "Social Capital as Post-Earthquake Recovery Strategy in Gondang Village, Gangga District, North Lombok Regency." The impact of the earthquake not only resulted in damage to infrastructure and, residential buildings, and other social facilities, but earthquakes also in psychological and of socio-economic life. This research is qualitative which aims to explain and find social capital owned by the community the postprocess in Gondang village, Gangga District, North Lombok Regency. The focus of this research is to find and identify forms of social capital in the village of Gondang, then how the form of social capital is used as a post-earthquake. This study the theory and concept of social capital from James $S$. Coleman was from his rational choice theory, data and information in-depth interviews, field observations and documentation. Data analysis are data reduction, data presentation, approval /verification, and credibility. The results showed the form of social capital in Gondang of beliefs, networks and norms. Community trust in religion, government, volunteers, and community members. The network from insideand outside relation, values and norms are still implemented by community as well as subak and the form of social capital traditions or customs sangkep, ngibukang, and nembakuh.
\end{abstract}

Keywords : Social Capital, Strategy, Post-Disaster Recovery, Earthquake

\begin{abstract}
Abstrak
Penelitian berjudul "Modal Sosial Sebagai Strategi Pemulihan Pasca Gempa Di Desa Gondang Kecamatan Gangga Kabupaten Lombok Utara'. Dampak gempa bumi tidak hanya mengakibatkan kerusakan infrastruktur, bangunan tempat tinggal, dan fasilitas sosial lainnya, tetapi gempa bumi juga berdampak pada psikologis dan kehidupan sosial ekonomi. Penelitian ini merupakan penelitian kualitatif yang bertujuan untuk menjelaskan dan menemukan modal sosial yang dimiliki oleh masyarakat dalam proses pemulihan pasca bencana di desa Gondang, Kecamatan Gangga, Kabupaten Lombok Utara. Fokus penelitian ini adalah untuk menemukan dan mengidentifikasi bentuk modal sosial yang ada di Desa Gondang, kemudian bagaimana bentuk modal sosial tersebut digunakan pasca gempa. Kajian teori dan konsep modal sosial dari James S. Coleman bersumber dari teori pilihan rasionalnya, data dan informasi menggunakan teknik wawancara mendalam, observasi lapangan dan dokumentasi. Analisa data melalui reduksi data, penyajian data, penarikan kesimpulan/verifikasi dan kredibilitas. Penelitian menunjukkan bentuk modal sosial masyarakat Desa Gondang terdiri dari kepercayaan, jaringan dan norma. Kepercayaan komunitas pada agama, pemerintah, relawan dan anggota komunitas. Jaringan terbentuk dari dalam dan luar masyarakat, nilai-nilai dan norma yang masih diimplementasikan masyarakat, yaitu gawe mati dan gawe hidup, serta sistem subak dan pakasih, wujud modal sosial tradisi atau adat istiadat berupa sangkep, ngibukang dan nembakuh.
\end{abstract}

Kata Kunci : Modal Sosial, Pemulihan Pasca Bencana, Gempa 


\section{Pendahuluan}

Indonesia merupakan salah satu negara yang berada di wilayah rawan terhadap berbagai kejadian bencana alam, misalnya bahaya geologi (gempa bumi, gunung api, longsor, tsunami) dan bahaya hidrometeorologi (banjir, kekeringan, pasang surut, gelombang besar). Hal ini mengingat wilayah negara Indonesia memiliki kondisi geografis, geologis, hidrologis, klimatologis dan demografis yang berpotensi terjadinya bencana, baik yang disebabkan faktor alam maupun non alam, seperti bencana yang disebabkan oleh faktor manusia. Keduanya dapat menyebabkan timbulnya korban jiwa manusia, kerusakan lingkungan, kerugian harta benda dan dampak psikologis (Haryono, 2012).

Bencana alam yang sering terjadi di wilayah Indonesia adalah gempa bumi. Hal ini dikarenakan kepulauan Indonesia terletak pada pertemuan tiga lempeng utama dunia yaitu lempeng Australia, Eurasia, dan Pasifik. Indonesia merupakan daerah pertemuan tiga lempeng tektonik besar, yaitu Lempeng Indo-Australia, Eurasia dan Lempeng Pasific. Lempeng Indo-Australia bertabrakan dengan Lempeng Eurasia di lepas pantai Sumatra, Jawa dan Nusa Tenggara, sedangkan dengan Lempeng Pasific berada di utara Papua dan Maluku Utara (Literasi Publik, 2018).

Peristiwa gempa bumi terjadi pada pukul 18:47, BMKG mengumumkan waspada tsunami. Keputusan ini diambil setelah menganalisis kedangkalan gempa, namun menimbulkan robekan akibat pergeseran sesar mulai dari daratan Lombok hingga wilayah laut, hal ini menimbulkan potensi tsunami. Walau kemungkinan ketinggian gelombang hanya setengah meter saja, namun warga diminta untuk waspada dan naik ke tempat yang lebih tinggi, namun tak lama kemudian bahaya tsunami ini ditarik oleh $B M K G$ pada hari yang sama

Berdasarkan Pasal 1 (9) UU 24/ 2007 Tentang Penanggulangan Bencana, Mitigasi bencana didefinisikan sebagai; "Upaya untuk mengurangi risiko bencana, baik melalui pembangunan fisik maupun penyadaran dan peningkatan kemampuan menghadapi ancaman bencana" (Faturahman, 2018). Permasalahan penting terkait dengan mitigasi bencana dan program yang terkait dengan proses pemulihan dan penanggulangan pasca bencana meliputi dua tahapan utama yaitu, rehabilitasi dan 
rekonstruksi adalah mengenai peran warga lokal, sebagai bagian dalam proses mitigasi bencana. Persoalan bencana bukan hanya mengenai berapa jumlah jiwa dan harta benda yang dapat diselamatkan, namun mitigasi bencana penting untuk lebih terfokus pada bagaimana penduduk dan harta benda dapat terhindar dari bencana. Salah satu unsur yang membantu keefektifan pemulihan bencana jika ada kerjasama dari seluruh komponen anggota masyarakat, berkerjasama dengan berbagai pihak lain yang memberikan konstribusi bagi penyelesaian permasalahan masyarakat lokal saat terjadi (Damayanti, 2016).

Melihat kondisi korban gempa, dengan keterbatasan dari segala aspek, masyarakat tidak akan mampu untuk memenuhi kebutuhannya sendiri tanpa adanya bantuan dari pihak lain, lumpuhnya sektor pariwisata_akan menyebabkan permasalahan ekonomi bagi masyarakat, karena sektor pariwisata merupakan mata pencaharian utama masayarkat Lombok Utara, sektor utama dalam meningkatkan pendapatan daerah Kabupaten Lombok Utara (KLU) (Bahersayah, 2019), peristiwa gempa bumi akan menjadi pertimbangan utama wisatawan untuk berkunjung ke Lombok. Proses rekonstruksi dan rehabilitasi akan membutuh waktu dalam proses pemulihan pasca bencana, lambatnya proses pemulihan bisa disebabkan oleh beberapa faktor, salah satu faktor penyebabnya yaitu kerjasama masyarakat yang kurang, karena tipisnya budaya sadar bencana. Jika ditelusuri lebih mendalam lagi, terdapat salah satu desa di Lombok Utara yang dalam proses pemulihannya efektif dan efisien. Penerapan unsur modal sosial seperti kepercayaan, nilai dan norma, serta jaringan mampu dimanfaatkan oleh masyarakat di Desa Gondang, yang digunakan sebagai strategi dalam proses pemulihan pasca bencana. Oleh sebab itu, peneliti tertarik untuk meneliti bagaimana "Modal Sosial Sebagai Strategi Pemulihan Pasca Gempa Bumi di Desa Gondang Kabupaten Lombok Utara“ dengan mem-fokuskan pada 3 unsur modal sosial yaitu kepercayaan, jaringan, dan nilai/norma. 


\section{Metode Penelitian}

Penelitian dilakukan saat bulan Juli 2019, mengambil lokasi di Desa Gondang Kecamatan Gangga, Kabupaten Lombok Utara yang merupakan salah satu yang menggunakan metode kualitatif dengan pendekatan studi kasus. Alasan peniliti memilih lokasi Desa Gondang, Kecamatan Gangga, Kabupaten Lombok Utara karena menjadi salah satu daerah terdampak bencana gempa. Tujuan penelitian ini adalah untuk mendeskripsikan bagaimana managemen penanggulangan bencana pasca-gempa, khususnya yang berkaitan dengan proses pemulihan yang terjadi di Lombok Utara. Pengumpulan data dilakukan dengan cara wawancara, observasi dan dokumentasi (menggunakan Handphone). Analisis data dilakukan dengan reduksi data, penyajian data dan verifikasi/penarikan kesimpulan.

\section{Hasil dan Pembahasan}

\section{Modal Sosial Desa Gondang dalam Proses Pemulihan Pasca Gempa Bumi}

Perkembangan proses rekonstruksi dan rehabilitasi Desa Gondang lebih cepat jika dibandingkan dengan desa lain, hal ini dapat dilihat dari jumlah pembangunan Rumah Tahan Gempa yang lebih banyak dibandingkan desa lain, artinya terdapat keinginan masyarakat untuk segera pulih dari ketertingggalan akibat bencana. Sinkronisasi antara masyarakat dan pemerintah yang baik merupakan perantara percepatan proses pemulihan, dalam hal ini tidak dapat terlepas dari peran modal sosial masyarakat Gondang. Modal sosial sangat berperan dalam proses pemulihan, adanya rasa percaya, nilai-nilai dan jaringan yang mampu mengakomodir setiap program yang ditargetkan oleh pemerintah, dengan melibatkan masyarakat sebagai aktor utama pemulihan.

\section{Bentuk Modal Sosial (Kepercayaan, Nilai-nilai dan Norma, dan Jaringan) Di Desa Gondang Kabupaten Lombok Utara}

Implementasi modal sosial sebagai sumber daya untuk mengakomodir segala potensi yang ada di Desa Gondang. Dengan mengoptimalkan potensi modal sosial seperti kepercayaan, nilai-nilai dan norma, serta jaringan sebagai strategi 
dalam proses pemulihan dapat meningkatkan kualitas kerjasama untuk bersinergi dalam proses pemulihan. (Field, 2011).

Adapun bentuk- bentuk modal sosial masyarakat Desa Gondang terdiri dari

Tabel 1.1 Bentuk modal sosial masyarakat di Desa Gondang

\begin{tabular}{|c|c|c|}
\hline No & Bentuk Modal Sosial & Keterangan \\
\hline 1 & Kepercayaan (Trust) & $\begin{array}{l}\text { Kepercayaan masyarakat terdiri dari kepercayaan } \\
\text { terhadap sesama anggota yang terikat oleh } \\
\text { persamaan persepsi, etnis, dan budaya. } \\
\text { Kepercayaan terhadap relawan yang bermitra dan } \\
\text { membantu dalam proses pemulihan merupakan } \\
\text { pihak yang memiliki keinginan ikhlas dan mulia } \\
\text { untuk membantu sesama. } \\
\text { Kepercayaan terhadap pemerintah yang } \\
\text { menetapkan reglasi dan kebijakan hukum dalam } \\
\text { proses pemulihan. } \\
\text { Kepercayaan masyarakat yang tumbuh oleh } \\
\text { pemahaman nilai-nilai agama menunjukkan } \\
\text { adanya sikap jujur, ikhlas, tabah, dan bertanggung } \\
\text { jawab. }\end{array}$ \\
\hline 2 & Jaringan (Network) & $\begin{array}{l}\text { Jaringan yang berasal dari dalam dan luar } \\
\text { masyarakat, jaringan dari dalam merupakan relasi } \\
\text { dari P3A dan KWT, sedangkan jaringan dari luar } \\
\text { merupakan Lembaga ACT yang bermitra dengan } \\
\text { Desa Gondang. }\end{array}$ \\
\hline 3 & $\begin{array}{l}\text { Nilai-Nilai dan Norma } \\
\text { (Norms) }\end{array}$ & $\begin{array}{l}\text { Kerjasama dan solidaritas masyarakat yang terikat } \\
\text { oleh nilai dan norma, tradisi gawe mati dan gawe } \\
\text { hidup, serta sitem subak dan pekasih dalam } \\
\text { pertanian yang mengatur pola kehidupan } \\
\text { masyarakat Desa Gondang. }\end{array}$ \\
\hline
\end{tabular}

Sumber: Data Primer Yang Diolah

\section{Kepercayaan}

Kepercayaan yang ada di_antara masyarakat yang terdampak menjadi salah satu faktor penentu keberhasilan program pemulihan, dengan menyadari bahwa bencana yang terjadi merupakan teguran dari Tuhan untuk umatnya, masyarakat Desa Gondang meyakini bahwa bencana yang terjadi harus dijadikan sebagai momentum untuk mendekatkan diri pada sang pencipta. Nilai agama menjadi dasar masyarakat untuk membangun rasa percaya dan berpikiran positif terhadap orang lain. Bekerjasama dalam proses pemulihan didasarkan dengan niat ikhlas untuk 
membantu sesama sebagai korban sepenanggungan, dan saling percaya bahwa kerjasama yang baik akan menguntungkan semua pihak yang terlibat.

Kepercayaan membuat perilaku individu-individu bertindak jujur dan mematuhi segala aturan. Kepercayaan tersebut mempererat simpul-simpul ikatan sosial sehingga antar komponen tersebut timbul kerjasama dalam pelaksanaan program. Sehingga masyarakat tidak berprasangka buruk atau mengawasi anggota masyarakat lainnya, yang akhirnya solidaritas masyarakat akan tercurahkan untuk fokus dalam menyelesaikan program dan hasil pembangunan tercapai secara maksimal. Hal terpenting adalah rasa koneksi dengan orang lain karena kita melihat mereka sebagai anggota komunitas kita sendiri yang kepentingannya harus ditanggapi dengan serius. Bukan berarti kepercayaan strategis bersifat negatif akan tetapi didasarkan pada ketidakpastian (Wibowo, 2012).

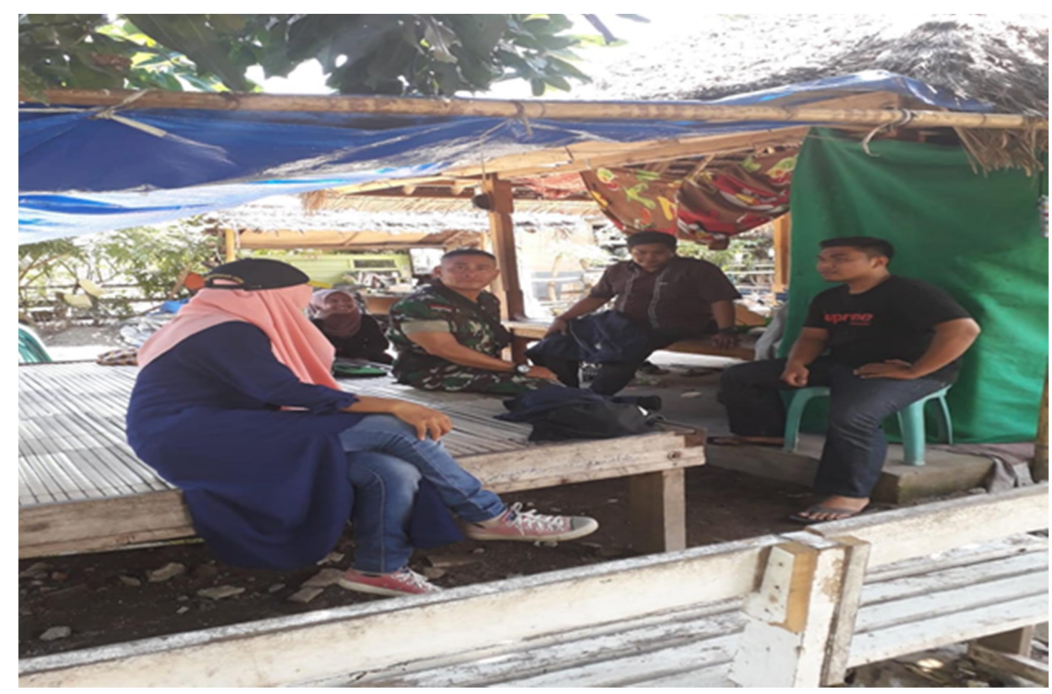

Gambar 1.1 Koordinasi Bintara Pembina Desa Di Desa Gondang

Dengan modal jujur dan saling percaya ini, maka masyarakat dapat membangun kerjasama dengan pemerintah. Kerjasama ini sangat penting karena menyangkut kelangsungan kehidupan masyarakat lokal, karena dalam kehidupan berbangsa dan bernegara masyarakat tidak terlepas dari pemerintah. Dalam proses pemulihan pasca bencana harus disertai dengan koordinasi yang baik antara 
pemerintah pusat, pemerintah daerah, dan masyarakat terdampak bencana, serta relawan yang berperan meminimalisir dampak bencana

\section{Jaringan (Network)}

Hubungan sosial bisa dipandang sebagai sesuatu yang seolah-olah merupakan sebuah jalur atau saluran yang menghubungkan antara satu orang (titik) dengan orang-orang lain di mana melalui jalur atau saluran tersebut bisa dialirkan sesuatu (Ruddy, 2007). Dapat ditarik suatu definisi mengenai jaringan sosial, yaitu suatu hubungan sosial yang melibatkan sekelompok orang dengan nilainilai atau norma-norma informal disamping nilai-nilai atau normanorma yang diperlukan untuk dapat menghubungkan orang yang dipandang sebagai titik dan hubungan sosial dipandang sebagai suatu saluran untuk mengalir sesuatu.

Masyarakat Desa Gondang menyadari betul bahwa mereka merupakan korban bencana yang masih membutuhkan uluran tangan, mengingatkan belum sepenuhnya lini kehidupan masyarakat kembali total sepenuhnya. Dengan memanfaatkan potensi relasi dan kemampuan masyarakat membangun kemitraan, masyarakat memiliki kesiapan untuk lebih sigap dalam menghadapi bencana. Beberapa jaringan yang bermitra dengan Desa Gondang seperti Japan Platform, Pecae Winds Japan, Integrated Community Shelter, Aksi Cepat Tanggap, Global Waqaf merupakan lembaga yang bermuara pada Lembaga Aksi Cepat Tanggap.

Jaringan dan lembaga-lembaga dibangun dan dikembangkan untuk membantu proses rekonstruksi dan rehabilitasi, partisipasi masyarakat lokal untuk ikut terlibat dalam setiap program dari Jaringan dan lembaga-lembaga merupakan strategi untuk membangun kedekatan dan hubungan emosional. 


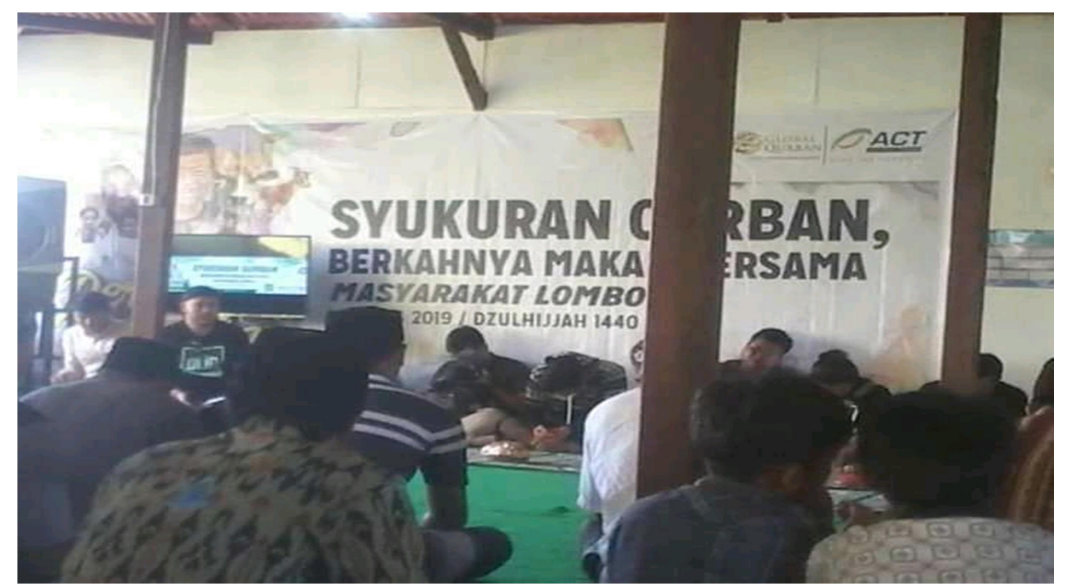

Gambar 4.2 Acara Syukuran Idul Adha

Sebelum bencana memang masyarakat sudah aktif untuk berorganisasi, organisasi yang lahir sebelum gempa dan masih eksis pasca bencana menambah jaringan atau relawan dari pihak luar, seperti Kelompok Wanita Tani yang berfokus pada bidang pertanian yang dibentuk untuk menyediakan dana simpan pinjam, bekerjasama dengan berbagai hotel yang membutuhkan hasil pertanian. Perkumpulan Petani Pemakai Air (P3A) yang bergerak pada saluran irigasi air, peningkatan kompetensi sumber daya manusia pengurus Petani Pemakai Air (P3A) diperoleh dari berbagai pelatihan.

\section{Nilai-nilai atau Norma}

Pengertian norma yaitu memberikan pedoman bagi seseorang untuk bertingkah laku dalam masyarakat atau seperangkat pedoman yang mengatur perilaku dari para anggota dan ada sanksi nyata dari pelanggaran yang terjadi. Kekuatan mengikat norma-norma tersebut berbeda-beda. Dikenal dengan empat pengertian yang disusun berdasarkan kekuatannya dari paling lemah hingga yang paling mengikat antara lain: cara (Usage), kebiasaan (Folkways), tata kelakuan (Mores), dan adat istiadat (Custom) (Soekanto, 2006).

Implementasi nilai-nilai kearifan lokal seperti gotong-royong, musyawarah, dan rasa kebersamaan yang masih pertahankan oleh masyarakat, dimanfaatkan sebagai strategi dalam mempercepat proses pemulihan. Implementasi nilai-nilai dan 
norma diharapkan mampu meningkatkan solidaritas masyarakat yang memiliki keterikatan, sehingga dapat meningkatkan kualitas koordinasi dan kerjasama.

Dalam perkembangannya, masyarakat pendatang di Desa Gondang banyak berasal dari Kabupaten Lombok Timur ( Kembang Kerang dan Tembaban) dan juga berasal dari Sumbawa (Bima dan Dompu) Lombok Barat dan Mataram sedangkan masyarakat dari Sulawesi yang mendiami wilayah pesisir terbanyak dari Bugis Makasar, dalam perkembangan masyarakat yang datang dari luar Desa Gondang membaur dan menyatu dengan masyarakat yang lainnya melalui proses perkawinan, dalam hetergonitas kehidupan masyarakatnya berkembang secara damai dan hidup dengan harmoni.

Masyarakat Desa Gondang memiliki nilai-nilai yang mewadahi dan mengatur kegiatan-kegiatan kolektif yang bermanfaat bagi seluruh warga masyarakat. Hal ini dapat dilihat dari tata cara mengelola lahan pertanian dengan menggunakan sistem subak dan pekasih dan dalam mengatur pengelolaan pertanian, sedangkan untuk mengatur tata pri-kehidupan masyarakatnya menggunakan sistem Banjar dan awig-awig.

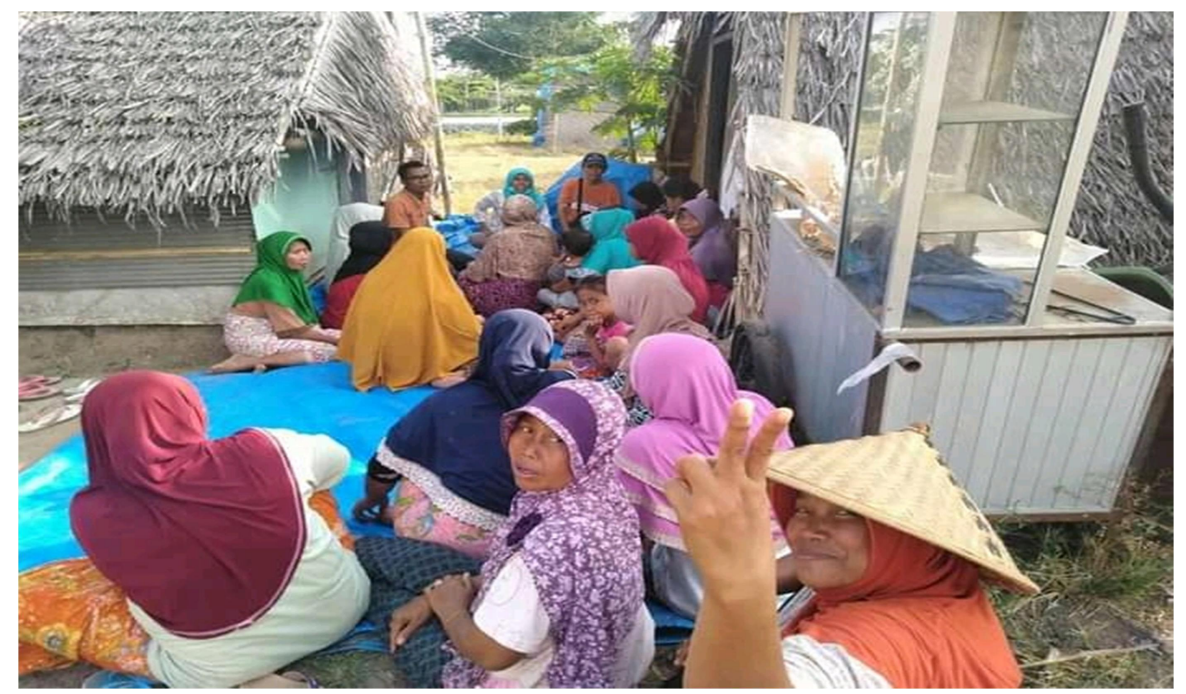

Gambar 4.3 Sangkep Evaluasi Kelompok Wanita Tani 


\section{Wujud Modal Sosial Sebagai Strategi Pemulihan Pasca Gempa Bumi Di Desa Gondang Kabupaten Lombok Utara}

Menurut Robert D. Putnam modal sosial merupakan bagian dari kehidupan sosial seperti jaringan, norma, dan kepercayaan yang mendorong partisipan bertindak bersama secara lebih efektif untuk mencapai tujuan-tujuan bersama. Sedangkan menurut Fukuyama (2002) bahwa unsur terpenting dalam modal sosial adalah kepercayaan (trust) yang merupakan perekat bagi langgengnya kerjasama dalam kelompok masyarakat. Dengan kepercayaan (trust) orang-orang akan bisa bekerjasama secara lebih efektif.

Menjadi masyarakat yang mengerti akan kondisi sosial yang sedang dihadapi, masyarakat harus mampu untuk berkonstribusi dalam setiap program pemulihan. Modal sosial yang dijadikan sebagai strategi pemulihan pasca gempa, mampu menggerakkan masyarakat untuk bersinergi dalam proses pemulihan. Implementasi modal sosial masyarakat pasca gempa akan menciptakan masyarakat yang memiliki inisiatif dan bergerak secara mandiri, partisipatif, jujur, ikhlas, serta terciptanya rasa sepenanggungan sebagai korban bencana.

Penerapan modal sosial bertujuan untuk meningkatkan kualitas rekonstrusksi dan rehabilitasi pasca gempa, strategi pemulihan yang diakomodir dengan adanya kepercayaan, nilai-nilai dan norma, serta jaringan dimanfaatkan untuk mempercepat proses pemulihan. Di dalam proses pemulihan pasca gempa, masyarakat senantiasa terikat pada nilai-nilai dan norma yang dijadikan sebagai pedoman untuk bergerak secara bijak. Strategi pemulihan pasca gempa masyarakat Desa Gondang meliputi kegiatan gotong-royong, rasa sepenanggungan dan solidaritas, pemanfaatan bantuan dari luar, serta partisipan warga lokal. 
Tabel 2.1 Wujud modal sosial masyarakat di Desa Gondang

\begin{tabular}{|l|l|l|}
\hline No & Wujud Modal Sosial & Keterangan \\
\hline 1 & Surykep (Musyawarah) & $\begin{array}{l}\text { Kegialan untuk mengumpulkan masyarakal secard } \\
\text { mensilaq untuk berdiskusi, penerapan tradsi sangkep } \\
\text { mampu menjaga rasa saling percaya dan solidaritas, } \\
\text { karena penyampaian informasi yang terbuka kepada } \\
\text { masyarakat. }\end{array}$ \\
\hline 2 & $\begin{array}{l}\text { Ngibukang (Gotong- } \\
\text { royong) }\end{array}$ & $\begin{array}{l}\text { Kegiatan bergotong-royong untuk meringankan } \\
\text { beban sesama, biasanaya dikerjakan untuk } \\
\text { mengadakan gawe idup atau gawe matimasyarakat } \\
\text { yang ikut membantu akan disuguhkan makanan } \\
\text { tradisional sebagai bentuk ungkapan rasa } \\
\text { berterimalkasih. }\end{array}$ \\
\hline 3 & $\begin{array}{l}\text { Nembakuh (Kerjasama } \\
\text { Membangun Rumah) }\end{array}$ & $\begin{array}{l}\text { Kegiatan bergotong-royong yang biasanya dibantu } \\
\text { oleh kerabat, keluarga, maupun tetangga, untuk } \\
\text { bersama-sama bekerja membangun rumah. }\end{array}$ \\
\hline
\end{tabular}

Sumber : Data Primer Yang Diolah

\section{Sangkep (Musyawarah)}

Sangkep yaitu istilah untuk mengumpulkan warga agar menciptakan suatu mufakat, baik saat tanggap darurat sampai pemulihan pasca bencana semua terlebih dahulu di musyawarahkan. Sangkep dijadwalkan oleh masyarakat setiap 2 kali seminggu saat awal pemulihan dengan melibatkan pihak relawa-relawan, artinya masyarakat memang sudah terbiasa untuk peduli terhadap situasi sosial. Masyarakat yang partisipatif akan mempermudah pemerintah untuk menginformasikan kebijakan serta regulasi terkait program pemulihan secara menyeluruh.

Dalam kehidupan sosial sehari-hari, setiap kegiatan masyarakat desa Gondang tidak dapat terlepas dari sangkep, terlebih lagi saat melakukan kegiatan keagaman, sehingga tidak terjai kecemburuan diantara masyarakat yang berakibat menimbulkan perpecahan. Dalam proses rekonstruksi dan rehabiltasi, setiap keputusan yang akan diambil terlebih dahulu akan diadakan sangkep, untuk menumbuhkan rasa percaya dan membentuk aturan yang dapat disepakati bersama. Selain itu, tradisi sangkep dapat merekatkan solidaritas masyarakat agar tetap kompak dan menjunjung tinggi rasa kekeluargaan, karena tetap terjalin interaksi diantara masyarakat yang dapat memperkuat tali silaturahmi. 


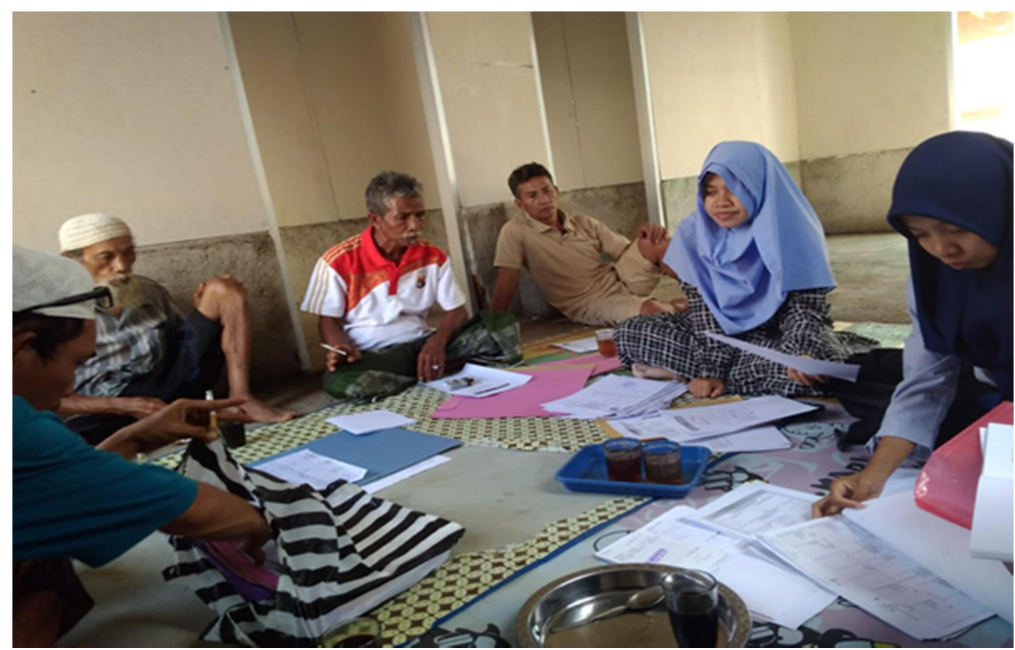

Gambar 2.1 Sangkep Pokmas

\section{Ngibukang (Gotong-royong)}

Ngibukang yaitu istilah untuk mengerjakan segala sesuau dengan berkrjasama, karena masyarakat sangat meyakini dengan berkerjasama setiap apa yang dikerjakan dapat terselesaikan dengan efektif dan efisien. Pembuatan tenda saat mengungsi, pembuatan shelter, hingga pembangunan rumah tahan gempa masyarakat kerjakan dengan ngibukang artinya setiap kegiatan program pembangunan tidak terlepas dari keterlibat dan peran aktif warga lokal.

Masyarakat Desa Gondang masih memegang erat budaya ngibukang, hal ini dapat terlihat sejak penanganan bencana sampai proses rekonstruksi dan rehabilitasi. Dengan menerapkan budaya ngibukang, masyarakat dapat menghemat biaya pengeluaran, pada dasarnya setiap kegiatan yang dilakukan oleh masyarakat, seperti saat melaksanakan acara pernikahan, acara kematian, dan setiap kegiatan yang membutuhkan banyak tenaga dalam pengerjaannya. Semakin aktif masyarakat yang terlibat dalam tradisi ngibukang maka akan semakin banyak pula masyarakat yang akan membantu, karena tradisi ngibukang dikerjakan berdasarkan niat untuk saling tolong-menolong dengan cara bergotong-royong.

Kehidupan masyarakat Desa Gondang tidak dapat terlepas dari tradisi ngibukang, karena pada dasarnya masyarakat Desa Gondang memiliki hubungan sosial yang tinggi, hal ini dapat terlihat dari setiap kegiatan yang dilakukan secara ngibukang, seperti acara pernikahan, pembangunan masjid, acara kematian dan 
acara-acara lainnya. Setelah bencana gempa bumi terjadi tradisi ngibukang masih diterapkan oleh masyarakat Desa Gondang, tradisi ngibukang sangat berpengaruh dalam proses pemulihan pasca bencana gempa bumi, mengingat kondisi sosial ekonomi masyarakat yang belum stabil sepenuhnya. Masyarakat akan semakin dikuatkan dengan interaksi dan silaturhami yang masih terjaga, dalam menghadapi bencana masyarakat akan semakin kompak dengan menerapkan tradisi dan nilainilai lokal yang mampu mengakomodir prores pemulihan pasca bencana.

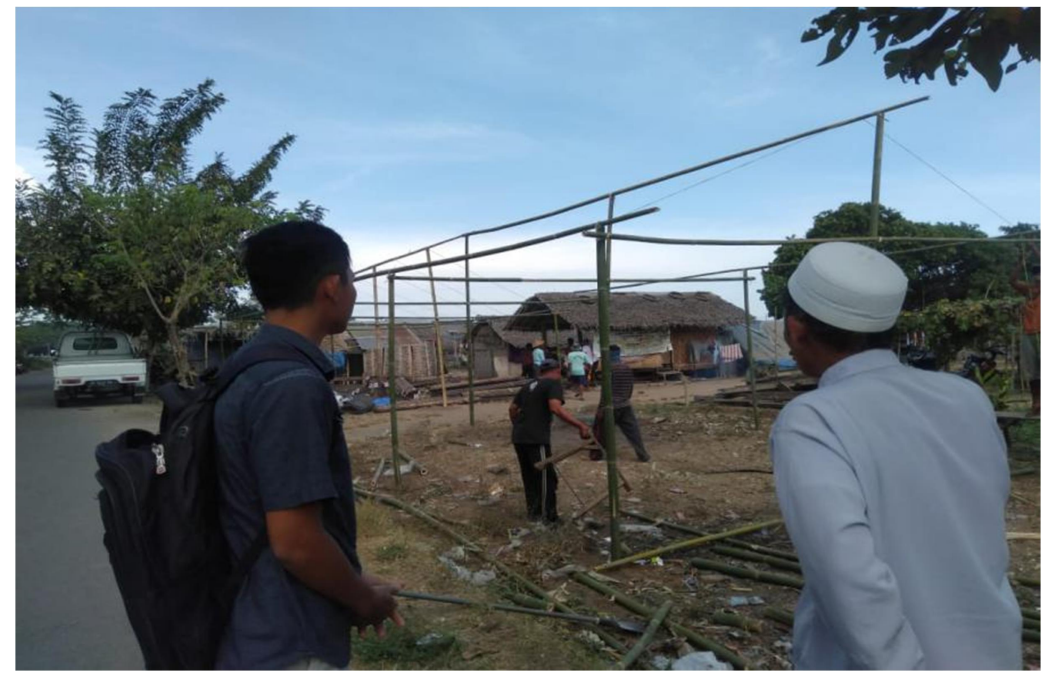

Gambar 2.2 Tradisi Ngibukang Acara Pernikahan

\section{Nembakuh (Kerjasama Membangun Rumah)}

Nembakuh merupakan kegiatan membangun dan mendirikan tiang rumah yang dikerjakan secara bergotong-royong, terlebih lagi saat masyarakat membangun rumah tahan gempa yang terbuat dari kayu, nembakuh biasanya dikerjakan secara bergotong-royong oleh sekelompok masyarakat yang memiliki hubungan ikatan, yang dibantu oleh pihak keluarga, kerabat, tetangga, dan masyarakat yang samasama membangun rumah. Nembakuh dikerjakan berdasarkan niat ikhlas untuk membantu sesama, apalagi saat bencana kondisi ekonomi masyarakat yang menipis, kemampuan masyarakat untuk memanfaatkan potensi yang ada mampu mempercepat proses pembangunan rumah tahan gempa. 
Masyarakat Desa Gondang menyadari pentingnya kerjasama untuk bersinergi dalam proses pemulihan, dengan memanfaatkan potensi dari interpretasi kebudayaan dan nilai-nilai yang diwariskan oleh nenek moyang. Tradisi nembakuh pada awalnya dibuat untuk membangun rumah Balaq (yaitu rumah tradisional yang terbuat dari kayu). Dalam membangun rumah tahan gempa, pada dasarnya hanya dikerjakan oleh tukang saja, tetapi untuk mempercepat proses pemulihan masyarakat Desa Gondang menyadari, bahwa konstribusi masyarakat sangat berperan dalam membantu pembangunan rumah tahan gempa. Dengan menerapkan tradisi nembakuh, masyarakat bisa membangun rumah dengan efektif dan efisien, sehingga masyarakat tidak perlu menunggu waktu yang cukup lama untuk dapat menghuni rumah.

Pemulihan rekonstruksi permukiman dan bangunan gedung harus melibatkan peran warga, yang didukung oleh tenaga konstruksi, didampingi akademisi, bekerjasama membangun rumah tahan gempa secara bergotong-royong. Mayoritas masyarakat mengharapkan rumah berbahan dasar lokal, seperti kayu, bambu, kelapa, dan ilalang, karena masyarakat ingin mengembalikan rumah tradisional warisan nenek moyang. Dengan melibatkan masyarakat lokal sebagai bantuan tenaga dalam proses pembangunan, pembangunan rumah tahan gempa dapat diselesaikan secepat mungkin.

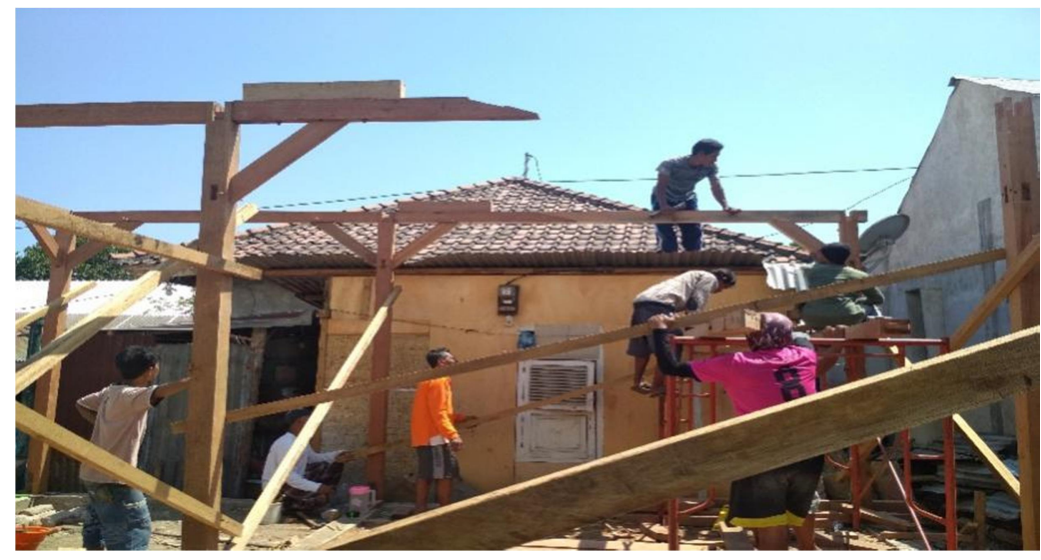

Gambar 2.3 Tradisi Nembakuh Pembangunan Rumah Tahan Gempa 


\section{Kesimpulan}

Berdasarkan analisa dan temuan data dalam penelitian ini, maka peneliti dapat menarik beberapa kesimpulan. Bentuk modal sosial masyarakat di Desa Gondang Kabupaten Lombok Utara terdiri dari kepercayaan, jaringan, dan norma. Kepercayaan masyarakat terhadap nilai-nilai agama, pemerintah, sesama anggota masyarakat, dan relawan. Nilai-nilai dan Norma yang masih diterapkan masyarakat yaitu tradisi Banjar gawe mati dan gawe idup, sistem pertanian dengan menggunakan tradisi Subak dan Pekasih. Jaringan dibagi menjadi jaringan dari dalam dan luar masyarakat, jaringan dari dalam merupakan relasi dari KWT dan P3A, sedangkan jaringan dari luar bermuara pada ACT. Wujud modal sosial masyarakat Desa Gondang merupakan interpretasi dari nilai kebudayaan dan tradisi masyarakat yang dijadikan sebagai strategi pemulihan pasca gempa yaitu Sangkep (Musyawarah), Ngibukang (Gotong-royong), Nembakuh (Kerjasama Membangun Rumah).

\section{Daftar Pustaka}

Agusyanto, Ruddy. 2007. Jaringan Sosial dalam Organisasi. Jakarta: Raja Grafindo Baheramsyah. 2019. Sektor Pariwisata Penyumbang Terbesar PAD Lombok Utara diakses dari http://infopublik.id/kategori/ekonomi-bisnis/364460/sektor-pariwisatapenyumbang-terbesar-pad-lombok-utara

Damayanti, Wardyaningrum. (2016). Jaringan Komunikasi Dalam fase Mitigasi Bencana (Analisis Struktur dan Kekuatan Ikatan Lemah (Weak Ties) pada Jaringan Komunikasi Masyarakat di Wilayah Rawan Bencana Gunung Berapi), (disertasi) Departemen Ilmu Komunikasi Universitas Indonesia, Jakarta.

Faturahman, Burhanudin Mukhamad. 2018. Konseptualisasi Mitigasi Bencana Melalui Perspektif Kebijakan Publik. PUBLISIA: Jurnal Ilmu Administrasi Publik, Volume 3, Nomor 2, Oktober 2018, 122- 134

Field, John. 2011. Modal Sosial (Alih Bahasa: Nurhadi). Yogyakarta: KreasiWacana

Fukuyama, Francis. 2002. Trust: The Social Virtue and the Creations of Properity. New York

Haryono, Tri Joko Sari, dkk. 2012. Model Strategi Mitigasi Berbasis Kepentingan Perempuan pada Komunitas Survivordi Wilayah Rawan Banjir. Departemen Antropologi, FISIP Universitas Airlangga. Vol. 25, No. 23, Juli-September 2012, $184-194$

Literasi Publik. 2018. Wilayah Indonesia Rawan Terhadap Bencana. Diakses dari https://www.literasipublik.com/wilayah-indonesia-rawan-bencana

Soekanto, Soerjono. 2006. Sosiologi Suatu Pengantar. Jakarta: Raja Grafindo

Wibowo, Yogo Mukti. 2012. Modal Sosial Pada Komunitas Motor Di Yogyakarta. Skripsi. Universitas Negeri Yogyakarta 